\title{
Brahmin, Monk, Astrologer, Medium: The Transition of the Master of Ritual of Lord Ganesha in Isan
}

\author{
Titiratana Wetsiriyanan ${ }^{1}$, Viyouth Chamruspanth ${ }^{1} \&$ Somsak Srisontisuk $^{1}$ \\ ${ }^{1}$ Department of Sociology, Faculty of Humanities and Social Sciences, Khon Kaen University, Thailand \\ Correspondence: Titiratana Wetsiriyanan, Department of Sociology, Faculty of Humanities and Social Sciences, \\ Khon Kaen University, Muang District, Khon Kaen Province, 40002, Thailand. Tel: 066-098-594-9142. E-mail: \\ titiratana.wetsiriyanan@gmail.com
}

\author{
Received: August 27, 2015 Accepted: September 15, 2015 Online Published: November 2, 2015 \\ doi:10.5539/ach.v8n1p76 \\ URL: http://dx.doi.org/10.5539/ach.v8n1p76
}

\begin{abstract}
People in today's society are faced with risk in everyday life, whether the risk is immoral condition, a natural disaster, political conflicts, or economic turmoil. People in society are also struggling competitively to survive. Problems that arise now are significant and are beyond the ability to personally manage. Moreover, people are looking for security in their society in order to survive. The belief in a supernatural power fits so perfectly as a solution to these problems and seems to answer the questions that are happening right now. People have many beliefs in various god figures. "Ganesha" god, is a tremendous success god who can eliminate all obstacles. It was selected by the prosecution to unravel the lives of most people in Thailand now. This paper was written to explore a social phenomenon and to create interest in this field of research. The researchers have found that a group of people taking turns to act as a key leader in the ceremonies related to beliefs in Ganesha by diverse groups. The researchers used qualitative research methods by in a case study approach. Data was collected through in-depth interviews.
\end{abstract}

Keywords: Lord Ganesha, belief, ritual, Isan

\section{Introduction}

Lord Ganesh, an important god for Brahmanism - Hindu Indians, has divine distinctive characteristics of a human body, and an elephant head, and is sitting on mice carrier. Wright (2005) stated that Indians usually respect and give first priority to respect to Lord Ganesha before other gods because he is the God of initiatives. Whether it's about doing something new, such as a house opening ceremony, a business opening, or a trip, Indian believers usually worship him before for the success of the activity. The reason why they worship Ganesha is because he is considered to be the oldest god among all Hindu gods. Ganesha is regarded as the god of various fields such as wisdom, arts, literary composition, harvesting, protection of village, and household god. Thongparn (2010) noted that Ganesha is the god of education, fertility, and obstacle remover. Most Indian placed a statue of Ganesh on top of the door or storefront as their household or store god. They generally performed reverence to Ganesh at home every morning. Every Indian worships Ganesha with regarding the images and other details.

Indrawut (n.d.) suggested that Ganesha is the god for every Indian village. In the middle of most village, there is a shrine for worshiping Ganesha. The statue is enshrined in a temple, fortress gate, or temple entrance for Siva worship.

The history of Southeast Asia shows that the Indian people have been in contact with people in the region since the prehistoric times (Disakul, 1979; Wolters, 1999(. The Indians in contact with the people of Southeast Asia were not only traders but also monks, missionaries, and priests. Along with them came Indian literature and culture, in particular the religious beliefs of both Brahmanism and Buddhism (Youpho, 1967; Yayah, 2003(. Marine travel stories appeared in several stories of Indian Buddhism which described the journey across the Indian Ocean towards the Suvarnabhumi region (Jerryson 2009). The early group of Indian traders came to trade goods with various groups in the Suvarnabhumi area and they settled on various ports in order to have a safe haven during the monsoon season. After the monsoon, then they returned to India. Previously, most people in lands worshiped spirits and angels and the Indians brought their Hindu religious piety in these territories. Indigenous peoples embraced the faith of Brahmanism in harmony with their traditional beliefs (Saraya, 2011).

Most Thai people have long been known that Ganesh is the god of arts and divinity. This is regarded as one of the original beliefs existing In Thailand (Zimmer, 1972; Endres \& Lauser, 2012). Most people perceived that belief of Ganesha was embraced only the ruling elite. Charoensuk (n.d.) found evidence of Ganesh shrines in the oldest 
archaeological sites in Khaoka, Nakhonsrithammarat province. Later the people of Thailand were influenced by the culture of the Khmer and Sukhothai. There were Sukhothai inscription in the wild of mangoes, these showed the signs of Ganesha respect which was influenced by the Khmer culture (Srirachlao, Chansuwan, \& Jantamala, 2013). Also Wattanamart (2005) and Kachacheewa (1988), proposed that in Ayutthaya, there was evidence of respect for Ganesha among the prominent elites that appeared in the annals of King Narai who ordered the building of a statue of Ganesha as the supreme elephant master several times. Ganesha was mentioned in King Narai's verses as well as in Ayutthaya ancient law. In the early Rattanakosin period, Ganesha was discussed mainly in elephant taming work (Schliesinger, 2015; Trautmann, 2015). In the reign of the King Rama V, was named for Ganasha and received a Ganesha idol from his father, King Rama IV who brought back a large Ganesha statue to Thailand after a trip to Java. (Now on display in the Thailand National Museum). King Rama VI particularly interested in the Indian studies. He worshiped Ganesha for prosperity and a success in his writings. This would make Ganesha to be regarded as the God of the Renaissance which was initiated by King Rama VI. He also built a shrine for Lord Ganesha in Sanam Chan Palace, Nakhon Pathom province. When Rama VI first created a literary club, Ganesha idol was given as the seal and the Department of Fine Arts and has been used in its seal since then.

When Thailand changed the government system during the reign of King Rama VII, belief about Ganesha was reduced (Brown, 1991). Later, during the reign of King Rama IX, belief in Ganesha revived when the country returned to a normal political condition. Today belief in Ganesha is found spreading among members of the general public (Brown, 1991). There are popular shrines of Ganesha and thousands more images of Ganesha in the temples, government organizations, companies, households, as well as in the cyber world.

\section{Research Question}

The research question in this article was: how do the people in Isan incorporate the worship of Ganesha into their daily lives and ritual?

\section{Research Methods}

The researchers used qualitative research methods. This confirmed the pluralistic perspective in the context where the research was studied. Data were collected through in-depth interviews. The selection of target groups in the study used specified method as known as the Case Study approach to get information on the overall transition of the ritual about Ganesha in Isan (Northeastern Thailand) in its entirety.

\subsection{Research Areas}

The researchers selected two study areas in the provinces of Nakhon Ratchasima and Surin. Because people in this area have worshiped Ganesh for a long time, their worship would be linked to observable transitions, rituals, the consequences of the belief in Ganesha in the lifestyle of people in the Isan.

\subsection{Data Access}

This study explored behaviors of faith of those who believe in Ganesha. The researchers realized that the issues for this study were particularly sensitive to participants. Access to information was started by building relationships with participants. The researchers observed in a consistent behavior and showed interests in studying about Ganesha for their own life. Researchers posed themselves as novices in the field of such beliefs who wished to pursue further knowledge in the correct practices. The expression of the researchers made the participants feel at ease and comfortably share and exchange experiences about their beliefs. Acting in a friendly, humility, and generous manner helped in every activity of research with the participants. In addition, some of the senior participants had received regular greetings cards to pay homage to them before the research began. When they meet the researchers in the rituals associated with Ganesh, they would automatically remember the researchers.

\subsection{Data Collection}

It was important to collect data for the study regarding to faith with a smooth and sincere expression. Researchers showed the expression of thought, speech, and behavior with consciousness, respect, and courtesy. This entailed a natural interaction during the interview sessions. This is important because the research was related to study of faith and supernatural powers. Researchers' attitudes were important to consider. Regarding the belief of supernatural power, we wanted to show respect to that belief itself.

\subsection{Data Analysis}

Researchers used the flexibility available approach to adjust the data analysis to be consistent with the participant groups and events that occurred during data collection. It was important for the retention of data to capture the delicate words of the interviewee. Researchers had to know the feelings and thoughts that come up during the conversation. Conversation about personal faith is a very sensitive issue. Researchers were conscious all the time 
and attention to every word carefully. As long as they exchanged or expressed information during the conversation, the researchers found it absolutely necessary to use common sense to observe the sensitivity of information provided by participants. It was crucial to keep a sense of participation. If the participant showed some characteristics that were indicative of uneasiness, the researchers would change the discussion topic and assume a relaxed the attitude immediately to accommodate the delicate feelings and circumstances at that time.

\section{Results}

\subsection{The Entry and Recognition of Ganesha Faith in Isan}

\subsubsection{The Entry of Faith in Ganesha in Isan}

The lifestyle of Isan people from past and present has been bound up with ghost stories and spirits (Mills, 1995). Consistent with Som-in (1991), asserting that ghosts and spirits have been a traditional belief for a long time which influences the worldview and lifestyle of the people. Ghosts, in the opinion of people in the Northeast, are seen as both demons and angels. Currently in Isan Buddhist, Brahmanism, and the spiritual beliefs are blended. The ritual in the life of the people in the northeast always have ghost stories involved. Whether holy ceremonies or events commemorating life events such as weddings, house warmings, and funerals; ghosts are included. It is believed that ghosts are real; some people admit to having witnessed ghosts.

In the past, Nakhon Ratchasima, also known as Korat, was an area that was associated with Brahmanism - Hinduism and where there was an ancient city that flourished ever since. The evidence of Brahmanism is clearly shown in the architecture and images of the Phimai temple which is one of the most important archaeological sites in the province. (Nakhon Ratchasima Chamber of Commerce, n.d.). Surin in ancient times was part of the Khmer empire (Yee, 2009). Historical evidence shows major signs of religious beliefs in Brahmanism - Hinduism in the architecture and images Sikhoraphum temple build in the $12^{\text {th }}$ century CE, locally called Ra-Ngang Castle. The art and architecture in its lintels reflects the influence of Khmer art of Angkor Wat, also constructed during the $12^{\text {th }}$ century CE. The lintel shows the dancer Shiva Raj, evidence to show that the temple was built for Lord Shiva in Brahmanism-Hinduism. (Ministry of Interior, 1999). Nakhonrachasima and Surin are relevant to the phenomenon of faith in Ganesha from past to present. Several ancient stone temples are prominent places, their images demonstrate that the provinces have joints faith in the religions Brahmanism - Hinduism. Other temples built during this Khmer influence period provide evidence of similar influence in different areas of the provinces. Currently in Nakhonrachasima, there are four key locations that have a relationship with the faith of Ganesha as follows: 1) The 38 million Ganesha Shrine is believed to be the original place of Lord Ganesha and spread a surge of faith in him, 2) Naraya Shrine is a place for the inauguration ceremony of wisdom (Birthday of Lord Ganesha), 3) Ganesha sandstone sculptures at Nong Sano village, Tambon Tha - Ang, Chok Chai district, Nakhon Ratchasima which is a village that produces cast idols of Ganesha, and 4) Pottery village in Dan Kwian, Chok Chai district, Nakhon Ratchasima. The village is famous for a long time for the making clay pots and a source of artistic idols and different Ganesha sculptures.

In Surin among the groups who honor Ganesha, sacred objects must be taken from Luangpu Hong (Grandfather Hong Brahmapunyo). The ceremony for the sacred idols is very sacred. People who own a business or a supervisor who wishes to manage their subordinates usually brings an elephant hook to Luang Pu Hong to chant in the ritual in order to enhance his or her prestige for maintaining their subordinates to respect and obey him or her. Importantly, when Surin reconstructed its city court from a traditional Chinese architecture to Khmer style, the Ganesha was a model idol in creating the new court. Moreover, the city court also has a Ganesha Museum as sacred symbol in the local called The Change Knowledge, too.

\subsubsection{The Recognition of Faith in Ganesha in the Isan}

Recognition of Ganesha by the former people in the Isan gave respect to supernatural powers. Later, when the Brahmanism - Hinduism and Buddhism had spread its influence to the region, people had to adjust and blend the two new faiths into Buddhism-Brahmanism, and Spirits. People in Isan modern society respect Buddhism as the main religion of the country (the official State religion), but the local Isan Buddhism (a synthesis of Buddhism and Brahmanism) is also heavily influencing the lives of the Isan people.

"Respect to the Buddha, you need to respect the Buddha first before you will pay homage to other angels."

(Oil, anonymous, interviews, September 18, 2012).

"I respect Buddhism. I will pray to the Buddha first. Then I will pay homage to various deities."

(Koi, anonymous, interview, September 18, 2012).

"I pay homage to Buddha first. After then I offer homage to Lord Ganesha."

(Ann, anonymous, interviews, September 18, 2012). 
The reason that the people express their respects to the Buddha first is, probably because Buddhism is the state religion and is the professed relition of $93 \%$ of the Thai people (Hackett et al., 2012). Also parenting during childhood, in particular, involves members of most Thai households going to a temple on a daily basis for such activities as offering food for the monks in the morning or follow their parents to the temple to make merit on the occasion and various religious and personal occasions. The education system states that Buddhism is the state religion and cultural norms reinforce Buddhist beliefs and activities giving people faith in Buddhism first then other beliefs come second.

\subsection{Practice of Ganesha Faith}

The evidence found in this research of the practice of faith in Ganesha among people in Isan was found in language (prayer/worship words), Ganesh cardinal ceremony, images, conversation, advertising, and the media.

\subsubsection{Language (Prayer/Worship Word)}

It was observed in this study that the hymns for worship of Ganesha were mostly in Sanskrit or Pali. Thai language was found a little in the prayers used by participants, which were composed in poems. The people did not understand the true meaning of the prayer because of the language barriers Sanskrit and Pali are not living languages. Participants had an overall understanding of the hymn to Ganesha and prayer for success to happen in their life. The group of people mostly pray to worship Ganesha with three hymns, a psalm of praise that is a heart of Ganesha (Om Srikanesa Yamaha), a psalm to worship Ganesha in 32 episodes, and the hymns of praise in 108 Ganesha's names. The popular chant among worshipers is called Heart of Ganesha.

\subsubsection{Ganesh Cardinal Ceremony}

It is important annual ceremony for the worship of Lord Ganesha and is believed to be the birthday of Lord Ganesha. The day usually occurs on the fourth lunar night on the tenth month. The Ganesh cardinal ceremony is frequently held in the court of King Narai, Nakhon Ratchasima. It is conducted over two days, the first day involves preparation of the site, various articles, and sacrifices. The second day is a day for the Ganesh festival fortifications with all-day activities.

\subsubsection{Images}

Images of Ganesh are generally shown with a smiling face demonstrating a gentle mood, fresh and cheerful. Groups of people who are respected consider the image of Lord Ganesh as encouragement to come up with their success.

\subsubsection{Conversation}

Conversation between the parties was reported by participants to have had the most influence on them and to encourage their faith in Ganesha. Direct discussion and questions among people have transferred inherited stories and experiences of faith about Ganesha.

\subsubsection{Publicity}

Publicity about faith of Ganesh is various in ways through television, print media (books, magazines), and mobile phones. Participants in this study suggested that publicity through television, by offering various forms of information, can influence people the most. It is because the worshiper can recognize images and clear sound through a TV presentation about the stories of faith in Ganesha that this would be effective.

\subsubsection{Digital Publicity}

Digital Publicity found in the area of cyber society has social influence, especially to extend the belief in Ganesha to spread out widely into different groups of society. The way of life and pattern of social life in modern society contribute to a society of information technology. People are interested in finding information through popular communication channels such as Facebook.

\subsection{Transition of the Ganesha Ceremony in Isan: Brahmin, Monk, Astrologer, and Medium Brahmin}

\subsubsection{Brahmin}

In the area studied Brahmin, means the person conducting the ceremony in Brahmanism - Hinduism who has an education of the history in Hindu gods and has learned how to follow the ancient tradition of the Hindu rituals in their religion. In this research it was found that the middle class and the wealthy in the Isan, the Royal Brahmin (Or Brahman in the Royal Palace in Bangkok) were usually been contacted as a leader in the rituals associated with Ganesha. The broadened social network groups provide opportunities for members of communities to understand and reach Brahmin. While the Northeast people have a general knowledge of Ganesha rather limited, they lack of understanding about the importance of worship deities in Brahmanism- Hinduism. They need a leader in the Brahmin rituals. In addition, the study also found that the people regards that a ritual must be conducted by a 
Brahmin. However, they still lack of the information about how to contact the Brahmin for the ceremony. The connection was related to methods and procedures as described in the following narratives.

"I have heard that conductor needs to be a Brahmin. But I do not know where I can find him."

(Noi, anonymous, interviews, September 19, 2012).

"Brahmin? I have heard about him. But I do not know that where to find him out."

(Pueng, anonymous, interview, September 19, 2012).

\subsubsection{Monks}

The monks in this study mean the monks or priests in Buddhism, who are the main conductors of ritual in a society where most people keep the Buddhist faith and respect. Because all the villages have a Buddhist temple as the center of faith and education in the community the monks have been selected to serve the role of training and transferring knowledge to people in the village. They also serve as conductors of rituals in community life from birth to death, such as an ordination ceremony, a naming ceremony, wedding ceremonies, funerals, etc. Monks are very close to the majority of society. This is why people are so familiar with Buddhism that if they have any ritual, monks must lead the ceremony. Monks are usually selected to serve as leaders in the rituals associated with Ganesha. In addition, television has advertised the Ganesha amulets for worshiping but the people do not know where to get the amulets. Community members frequently request monks to supply them to the temple because people have thought that the temple is a sacred place, so it should supply the amulets in the holy temple for the villagers to worship.

\subsubsection{Astrologer}

Local astrologers for ceremonies are secular, both male and female. Most are aged from 40 years up, sometimes known as a Brahmin astrologer by local villagers. In the past, the study of astrology could be done by men, especially the study of ceremonies and magic mantras. Transition of social conditions accommodates equal space in lifestyle for both men and women. This research found that women now play a role astrology in Isan.

"Previously there were men astrologers of which the ceremony will be led. Recently for ten years, I have seen more woman astrologers in the ceremony. Astrologer Oil is the first woman astrologer I have known. It is doubt that some men astrologers may not strict behaviors. They supposed to conform to the Eight Precepts. It is impossible to misbehave at all causes."

(Kiew, anonymous, interview, January 9, 2013).

"But first we only have men astrologer. Women are not allowed to learn astrology as well as its ceremony. However, I like and interested astrology for a long time. I'm self-educated. I buy self-study books, and browse in the Internet. Astrologer must have access to a teacher."

(Oil, anonymous, interviews, January 10, 2013).

\subsubsection{Medium}

Spiritualist mediums, in this research, are the people who can communicate with spirits and supernatural powers. They are men, women and transgender. At. Results in this research showed that a medium can be a man, a woman, or transgender and the spiritualist is at least 15 years old. The medium has a house as a place for ceremonies. People can come to communicate with medium to commune with spirits and gods including Ganesha. This research found that most people will come to pray to gods for good fortune, money, and success in life. This research also found that some mediums act as god of power to cure illness. In addition, several mediums predict the fate and future of the people. Because study and serious scholarship is not required of the medium, they are usually chosen by god to help people's lives.

\subsection{Belief in Ganesha of the Isan}

Belief in the supernatural or animism is the belief that firmly associated the life of the Isan. Ghost in the worldview of them were divided into protective ghost and evil ghost. When faith of Ganesha has a role in this region, they are still not understand the divine presence and also have a relatively limited knowledge about Ganesha. Any rituals about Ganesha, they look for local people to do such duties. Results were as the following.

The results of the faith in Ganesha on people and society that has two aspects: positive and negative. The positive effects included psychological and values, behavior in social interaction, groups of respected, and social / economic class paradigm. 
Mind and values of the prayer found that praying is the hope (or targets) to the life of Anglicans in that time. Blessing is what they think to tackle with a problem or an obstacle in their life, so they wish for eliminating them and adding extra encouragement to have hope. When blessings incorporate with hope, they will have to change how to think about problems in a new way for a positive changes and new obstacles to become diminished as blessing with wishes. When success comes up frequently, they are more confident in themselves.

Social interaction behaviors occurred in a ceremony that drew Ganesh believers. They were diverse groups of believers who had gathered in the same space, and who talked with each other to exchange ideas, and who see each other often. In turn, these people formed subnetworks to have social organizations in the area of the sacred rites as in the ritual of Ganesha fortifications.

This research showed a diminishing of social class gaps. According to the worship of Ganesha, people of all classes should have equal blessings from him. Ganesha cardinal ceremony drew people to the same ceremony. The interpersonal interaction in the area of faith formed a group without stratification. Economic paradigm found that capitalist society embraced Ganesha in livings. For example, the garden and landscape designers appointed to the beliefs of Ganesha by reproducing Ganesha statues in many different forms for decorative purpose. Other interesting observations about the two main groups of Ganesha believers, first that possess image of the neighborly kindness, courtesy, smiley face, as well as they became vegetarianism. The negative effects found in gambling expectation. They wished to win lottery prize from the belief on Ganesha blessing power. They spent a lot of money with dedication to achieve success in such an instance.

\section{Discussion}

Although today's society is a digital age and scientific advances are used to facilitate many activities of life of people in this society. The motions of life of the people may see the ease of communication and the convenience of living with the use of modern technology. However, technology is unable to take care of life and meet the people's needs comprehensively. We have seen pictures of "Ghost Culture" which is traditional cultural beliefs of the Isan people who believe in supernatural powers. There is popular belief of Ganesha. But most of the Isan's belief is still ambiguous about the understanding of the true state of Ganesha. They have embraced the faith. In a spirit culture linked to the status of Ganesh. It is said that the people has led the cultural of spirit with their original ancestor and tied with Ganesha. In the understanding of the local people, Ganesha is probably a ghost. As Som-in (1991) proposed, the Northeastern people have the belief in ghosts and spirits. Ghost in their opinion has both good demons and bad ghosts. So in the world of their Ganesha, he is probably the one that gives them the kind of ghost. They worship monk for the duties of the priesthood who may serve to alleviate mental distress. But in real life, people are suffering, both physical and mental; they tend to rely on the power of the mind to heal the suffering to a certain extent. To the belief in supernatural powers, Ganesha can relieve both physical pain and mental suffering. Monk also related to the authority relevant to the sin and merit in the way of suffering relief. Monk can be a relief to bring those who practice to the world or life after death. By the power of the devil, it can protect the lives and aspire to fulfill the desire in the current world.

In short, Northeast people also has a set of knowledge about the history and information about Ganesha, but somewhat limited. However, they hope just to rely on the healing power of Ganesha for the success and to eliminate all barriers in Brahmanism-Hinduism. People are usually persuaded by acquaintances, or heard, or seen Ganesha in the media. But they lack of understanding in the true state of the gods. This ambiguity leads to uncertain and confused understanding of the status of Ganesha. This ambiguity sets in cognitive status of god is spreading to various groups. Some misconceptions have taken advantage of such ambiguity. The ritual related to Ganesha should have been considered comprehensively. Tambiah (1970a, 1970b) suggested religious ritual forms between local beliefs and Buddhism by ritual ceremonies in some characteristics: Buddhist rituals by monk, welcome ceremony performed by Brahmins in the village. This is related to Hayashi (1985) in terms of ritual explanation. Although the ceremony of Brahmanism in local is called Brahmanism ritual, the truth is not associated with the transmission of tradition and knowledge of Brahmanism yet. The village's Bramin plays a key role in the rituals. More important, villagers conducted ritual by regarding to ghost of ancestors, village ghost who protect to area. Brahmins are the elders to act as the psychics and shaman rituals. Rituals are believed to get rid of evil spirits and operated by local Brahmins. In summary, the study has revealed the ways of beliefs of Isan people by related to Ganesha and others.

\section{References}

Brown, R. L. (Ed.). (1991). Ganesh: studies of an Asian god. SUNY Press. http://dx.doi.org/10.2307/1399629

Charoensuk, C. (n.d.). Ganesha, the god of tremendous success. Bangkok: Carat Diamond Publishing. 
Disakul, S. (1979). Historic South-East Asia to the Buddhist Years. Bangkok: Prime Minister's Office Press.

Endres, K. W., \& Lauser, A. (Eds.). (2012). Engaging the spirit world: Popular beliefs and practices in modern Southeast Asia (Vol. 5). Berghahn Books. http://dx.doi.org/10.1111/1467-9655.12138_29

Hackett, C., Grim, B., Stonawski, M., Skirbekk, V., \& Potančoková, M. (2012). The Global Religious Landscape. Pew Research Center.

Hayashi, Y. (1985). A Temple, Rituals and World - View in Don Daeng: A Rice Growing Village Revisited: An Integrated Study of Rural Development in Northeast Thailand. Kyoto: Center for Southeast Asian Studies.

Indrawut, P. (n.d.). The idols of the Hindu. Bangkok: Silapakorn University Press.

Jerryson, M. (2009). Appropriating a space for violence: State Buddhism in southern Thailand. Journal of Southeast Asian Studies, 40(01), 33-57. http://dx.doi.org/10.1017/s0022463409000034

Kachacheewa, J. (1988). Lord Ganesha: Beliefs and forms of Ganesha in Thailand. Bangkok: The Fine Arts Department.

Mills, M. B. (1995). Attack of the widow ghosts: gender, death, and modernity in Northeast Thailand. Bewitching women, pious men: Gender and body politics in Southeast Asia (pp. 244-273).

Ministry of Interior. (1999). Local history: the history of the historic districts in the.East and Northeast. Bangkok: Department of the Interior.

Nakhonrachasima Chamber of Commerce. (n.d.). Retracing 100 years of Korat commerce. Bangkok: Future Press and Media Publishing.

Saraya, T. (2011). Historical Indian Ocean. Bangkok: Ancient City Publishing.

Schliesinger, J. (2015). Elephants in Thailand Vol 2: Through the Ages (Vol. 2). Booksmango.

Som-in, A. (1991). Isan Worldviews. Mahasarakham: Mahasarakham University Press.

Srirachlao, M., Chansuwan, P., \& Jantamala, U. (2013). A Form of Conservation and Inheritance for Ceremonial Dance in Ancient Ruins of Southern Isan. Asian Social Science, 9(7), 200. http://dx.doi.org/10.5539/ass.v9n7p200

Tambiah, S. J. (1970). Buddhism and the Spirit Cults in Northeast Thailand. Cambridge: Cambridge University Press.

Tambiah, S. J. (1970). Buddhism and World Activity. Modern Asian Studies, 7(1), 1-20.

Thongparn, S. (2010). India starts here Tamil Nadu. New York: Ancient City Publishing.

Trautmann, T. R. (2015). Elephants and Kings: An Environmental History. University of Chicago Press. http://dx.doi.org/10.7208/chicago/9780226264530.001.0001

Wattanamart, K. (2005). Tri-god Exposition. Bangkok: Creative Book Publishing.

Wolters, O. W. (1999). History, culture, and region in Southeast Asian perspectives (No. 26). SEAP Publications. http://dx.doi.org/10.5512/sea.2001.147

Wright, M. (2005). Ganesha: the Hindu god in Indian Subcontinent and Southeast Asia. London: Matichon Press.

Yahya, F. (2003). India and Southeast Asia: Revisited. Contemporary Southeast Asia, 79-103. http://dx.doi.org/10.1355/cs25-1e

Yee, W. W. (2009). A Preliminary Study on some Economic Activities of Khmer Empire: Examining the Relationship between the Khmer and Guangdong ceramic Industries during the 9th-14th Centuries (Doctoral dissertation).

Youpho, T. (1967). Knowing the National Museum in Bangkok. Bangkok: Siwaporn Publishing.

Zimmer, H. R. (1972). Myths and symbols in Indian art and civilization (Vol. 6). Princeton University Press.

\section{Copyrights}

Copyright for this article is retained by the author(s), with first publication rights granted to the journal.

This is an open-access article distributed under the terms and conditions of the Creative Commons Attribution license (http://creativecommons.org/licenses/by/3.0/). 